\title{
Review of The British Superhero
}

\author{
Jones, Dyfrig
}

\section{European Comic Art}

DOI:

10.3167/eca.2019.120107

Published: 01/06/2019

Peer reviewed version

Cyswllt i'r cyhoeddiad / Link to publication

Dyfyniad o'r fersiwn a gyhoeddwyd / Citation for published version (APA):

Jones, D. (2019). Review of The British Superhero. European Comic Art, 12(1), 122-124. https://doi.org/10.3167/eca.2019.120107

\footnotetext{
Hawliau Cyffredinol / General rights

Copyright and moral rights for the publications made accessible in the public portal are retained by the authors and/or other copyright owners and it is a condition of accessing publications that users recognise and abide by the legal requirements associated with these rights.

- Users may download and print one copy of any publication from the public portal for the purpose of private study or research.

- You may not further distribute the material or use it for any profit-making activity or commercial gain

- You may freely distribute the URL identifying the publication in the public portal ?
}

Take down policy

If you believe that this document breaches copyright please contact us providing details, and we will remove access to the work immediately and investigate your claim. 
As Murray explains in the introduction to this new volume, superhero comics are a predominantly American genre; their narratives located in the great American cities - both real and imagined - their mission to protect and advance the "American Way". Yet while the USA has largely defined the genre, and American companies have led in publishing superhero narratives, Murray also argues that non-Americans have both contributed to the development of the American superhero, and also produced superhero narratives that explore, expand and comment upon the genre. In this new book, Murray offers an account of the development of the British superhero from the emergence of Victorian "Protosuperheros" to the present day. In doing so, he has made an important contribution to the relatively new field of Superhero Studies.

Parts of the book build upon work previously published by Murray, discussing Alan Moore, Grant Morrison and the "British Invasion" of American comics in the 1980s and 1990s. It is here that the book is at its strongest, and the chapter entitled Revisionism and the British Invasion, 1981-1993 is an excellent critical account of this period. Murray explores the contemporary influences - cultural, social and political - that helped to shape the work of Moore, Morrison, Neil Gaiman and others during this period. British revisionist superheroes, written by British writers for American publishers and audiences, are 
presented as anarchic commentaries on American cultural power, viewed through the lens of MTV and post-punk. But more importantly, Murray is able to locate the innovations of the 1980s within their broader historical context, arguing that the revisionism of this period was rooted in a long-standing tradition of British superheroes that parodied their American cousins.

Outlining this tradition is one of the key concerns of book's earlier chapters, where Murray provides an encyclopeadic account of the early development of the British superhero. His history begins with the "Protosuperheros" that emerged from $19^{\text {th }}$ Century popular fiction, and goes on to examine the way in which these characters shaped the development of British comic book characters in the $20^{\text {th }}$ Century. Murray identifies characteristics that distinguish British and American superheroes from each other, arguing that British superheroes often oscillate between aping the rhetorical strategies of American superhero comics, and undermining them through parody. But the book also describes the relationship between American and British comic publishers, and the way in which American superhero comics were adapted for a British readership. Not only does this aspect of the book provide fascinating insight into the industrial process of early comic book production in the UK, it also illustrates the broader cultural dynamics that informed British graphic storytelling during this period. 
This is comprehensive book that is densely populated with characters, both familiar and obscure. While this aspect of the work will make it an invaluable work of reference, the author's desire to be so comprehensive does slightly diminish it as a critical text. Many of the comics and characters discussed in the earlier chapters are simplistic and highly derivative, both of each other and of American superhero comics of the same era. As a result there is relatively little critical mileage to be gained from analysing them, and the second and third chapters of the book - dealing with the period from 1936 to 1961 - are a little repetitive in parts. These are two substantial chapters, taking up over a third of the book's 283 pages, and it may have been a stronger volume had these chapters been condensed. Rather than feeling an obligation to survey the entire field, the author could well have selected a smaller number of characters and publications, and used these as case studies to illustrate his argument about the general development of the British superhero during the middle of the 20th Century.

The book's other weakness is its reluctance to interrogate Britishness as a concept. To Murray's credit, in the introduction he addresses the tension that exists between a monolithic, artificial "Britishness" and the complex, multi-layered identities of those who live in the four constituent nations of the UK. The place of Dundee in the history of British comics is discussed - 
as would be expected of a book whose author resides in the city - and there is some discussion, here and there, of characters and publications that challenge an Anglocentric view of Britishness. But this element feels, at times, marginal and more could be done to examine the relationship between the British Superhero and the concept of Britishness throughout the book. It is, once again, in the chapter that deals with the 1980s and 1990s that the author best addresses this question, reflecting perhaps the fact that this is where Murray is most able to sink his critical teeth into his subject.
A book that was less at pains to give equal space to each historical era might have been a stronger one. The earlier chapters could well have been shortened, allowing more space for the author to delve in greater detail into the 1980s and 1990s. But such a book would, arguably, have been less authoritative, and have less value as a work of reference. As it stands, The British Superhero presents an excellent overview of the field, and will be an essential text for anyone wishing to undertake further research into the topic. 